\title{
Erratum to: Clinical Management of Ebola Virus Disease Patients
}

Karen K. Wong, MD, MPH*

Timothy M. Uyeki, MD, MPH, MPP

\section{Address}

*1600 Clifton Rd NE MS C-09, Atlanta, GA, 30329, USA

Email: kwong@cdc.gov

Published online: 30 September 2015

(C) Springer Science+Business Media New York 2015

The online version of the original article can be found at http://dx.doi.org/

10.1007/s40506-015-0053-5.

Erratum to: Curr Treat Options Infect Dis (2015) 7(3):248-260 DOI: 10.1007/s40506-015-0053-5

Under "Fluid and electrolyte replacement," the text "Potassium replacement needs may range from 0 to $630 \mathrm{mmol}$ per day" should read "Potassium replacement needs may range from 0 to $630 \mathrm{mmol}$ per admission." 